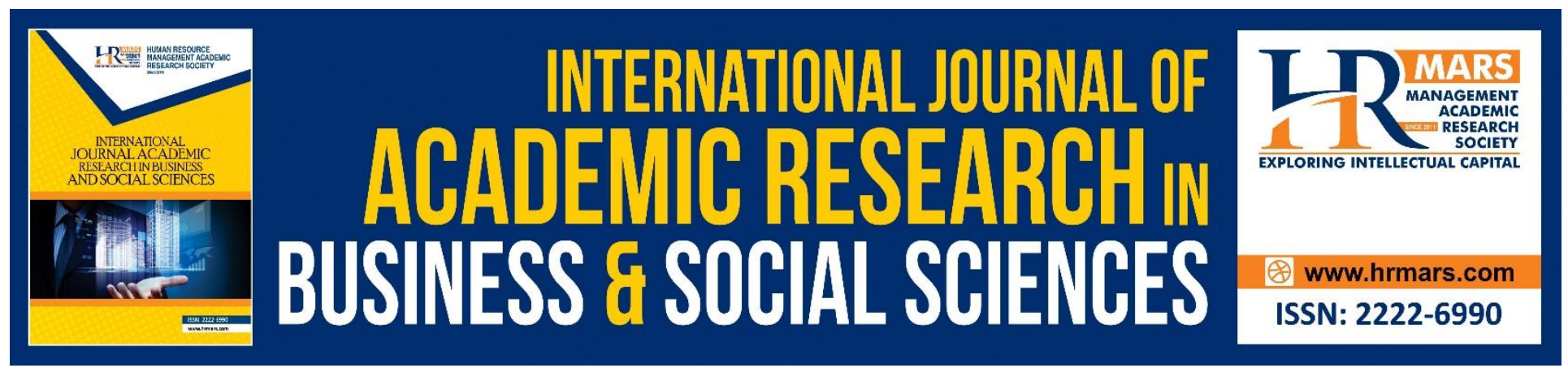

\title{
Factors of Work Life Balance and its Influence on Job Satisfaction in the Service Industry
}

Veniisa A/P Mani, Smitha Geetha, Akram Abdulraqeb Sultan Al-Khaled

To Link this Article: http://dx.doi.org/10.6007/IJARBSS/v10-i7/7472

DOI:10.6007/IJARBSS/v10-i7/7472

Received: 09 April 2020, Revised: 11 May 2020, Accepted: 17 June 2020

Published Online: 29 July 2020

In-Text Citation: (Mani, Geetha, \& Al-Khaled, 2020)

To Cite this Article: Mani, V. A/P., Geetha, S., \& Al-Khaled, A. A. S. (2020). Factors of Work Life Balance and its Influence on Job Satisfaction in the Service Industry. International Journal of Academic Research in Business and Social Sciences. 10(7), 571-589.

Copyright: (C) 2020 The Author(s)

Published by Human Resource Management Academic Research Society (www.hrmars.com)

This article is published under the Creative Commons Attribution (CC BY 4.0) license. Anyone may reproduce, distribute, translate and create derivative works of this article (for both commercial and non-commercial purposes), subject to full attribution to the original publication and authors. The full terms of this license may be seen

at: http://creativecommons.org/licences/by/4.0/legalcode

Vol. 10, No. 7, 2020, Pg. 571 - 589

http://hrmars.com/index.php/pages/detail/IJARBSS

JOURNAL HOMEPAGE

Full Terms \& Conditions of access and use can be found at http://hrmars.com/index.php/pages/detail/publication-ethics 


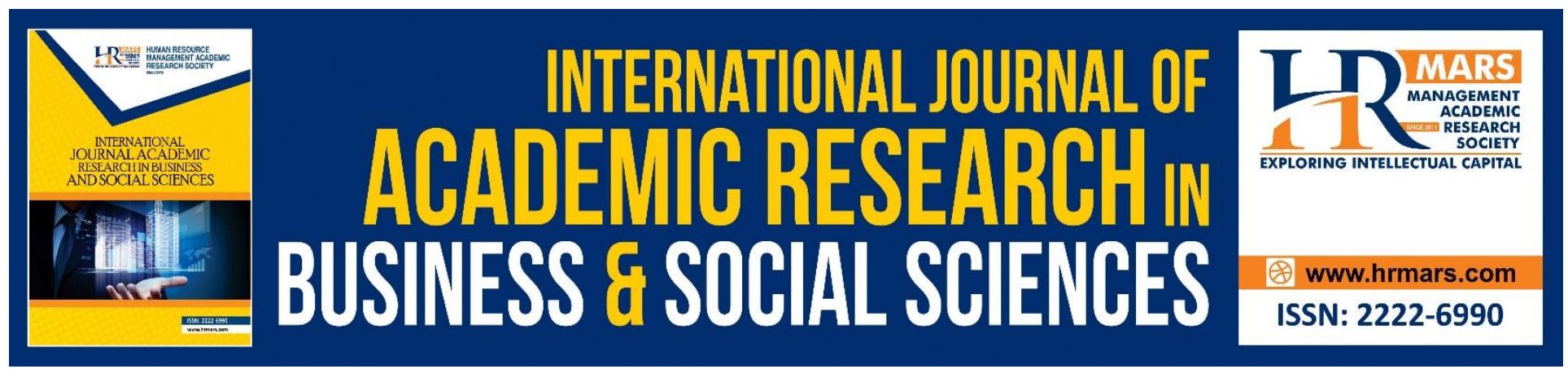

\title{
Factors of Work Life Balance and its Influence on Job Satisfaction in The Service Industry
}

\author{
Veniisa A/P Mani \\ Berjaya University College, Malaysia \\ Dr. Smitha Geetha \\ Faculty of Business, Berjaya University College, Malaysia \\ Dr. Akram Abdulraqeb Sultan Al-Khaled \\ Faculty of Business, Berjaya University College, Malaysia
}

\begin{abstract}
Work life balance were once considered as a priority. As the world changes, the increase of work pressure has made work-life balance impossible. The purpose of this research was to identify the factors that influenced the employee satisfaction. The range of definition of job satisfaction means that there are many ways job satisfaction can be defined. The research design that was used in this research project were quantitative methods. Quantitative method was suitable because it was able to gather a large sum of data. The descriptive statistics were used to provide a brief description of the samples and the measures that were taken in the particular study. Reliability test, normality test, correlation analysis and multiple regression test were used in analyzing the data. Overall analysis showed that the all the items in this research were reliable and consistent. The normality test showed that the data for skewness value and kurtosis value were all within their range and most of the item were normally distributed. There was a positive relationship between all the independent variables and dependent variables. Information that was collected from this research will deemed useful as it may be a way to create strategies to improve the employees well-being.
\end{abstract}

Keywords: Work Life Balance, Job Autonomy, Flexible Working Schedule, Emotional Intelligence, Job Satisfaction.

\section{Introduction}

The service world consists of multiple business sectors that focuses on providing service to customers. The service industry is growing rapidly over the past few years. With the growth of the service industry, many companies set their goals high and these forces employees to increase their commitment to the company. It has set a pressure on employees to work long hours and dedicate themselves to provide the best service to the customers. This also includes working on public holidays 
and sacrificing their own personal time to satisfy the company and to earn extra income. It is essential for organizations in the service industry to prioritize work life balance of their employees. By practicing a balanced with job and personal life, it will manipulate the level of satisfaction in employees. If the employees are dissatisfied with their work, they will not accomplish the best. Employees that are satisfied have high performance in their job are a major asset to the organization. In a company, it is the duty of the human resources and manager to understand each employee and what they need and what motivates them to perform at their best. Therefore, the objective of this study was to identify the relationship between work-life balance and job satisfaction. It is crucial to find the relationship between the two because the employee turnover rate is high in the service industry. The employee turnover rate are normally affected by employee discontentment with the work environment, the conditions of the works, salary and the cost of turnover greatly impact other establishment too(AlBattat, Som \& Helalat, 2014).This research studied the factors that leads to a balanced work life and how it leads to employee job satisfaction.

\section{Research Background}

Work life balance were once considered as a priority. As the world changes, the increase of work pressure has made work-life balance impossible. Studies on work / life balance issue has been conducted out in modern worldwide environment due to the awareness impact of the competitive working environment (Omar, Mohd \& Ariffin, 2015).The work-life balance can affect worker satisfaction as well as personal liberty (Omar, Mohd \& Ariff, 2015). Work-life balance is about developing and sustaining a safe work atmosphere that helps workers to balance work and private life and enhance the efficiency of workers (Dhas, 2015).A research found that 1 in 4 workers reported a high degree of work-family tension and one of the most significant factors affecting the work-life balance was the amount of hours spent on the job (Dhas, 2015). Failure to secure a work-life balance can lead to severe emotional stress and poor workplace productivity (Rao, 2016). Productivity of an employee may be effected due to working over 9 hours. The more strain the workplace causes, the harder it is to sustain a work-life balance and this leads in low motivation and life balance. Some employee work too much and do not have enough time to do other things in their everyday life. Over time, the barriers between work area and home have dissolved (Rao, 2016). With the advancement of technology, employees now have to synchronize both their personal and professional lives and they find themselves working even during their holiday. This inhibits the growth of an individual in terms of their personal growth and they eventually give up learning new things and give in to working long hours. In a study conducted, $83.33 \%$ woman employees said that the work life balance that was given to them was not good. It was revealed that they may be under stress due to the lack of worklife balance (Kshirsagar, 2018). They even mentioned that it may effect the relationship they have with their family, spouse and their health overall. Another study was done and it resulted that changes in physical conditions of work such as working hours, rest pauses, fatigue, incentive, employee attitude results in high employee satisfaction (Kshirsagar, 2018).Another study found that many Western companies understand the importance of work-family culture and implement worklife balance strategies such as flexible work arrangements to improve job satisfaction (Wong, Bandar \& Saili, 2017).The Kelly Global Workforce Index (KGWI) claimed that two-third of Malaysian prefer a balanced work-life compared to higher salary (Wong, Bandar \& Saili, 2017). The research intention was to identify the factors that influences the employee satisfaction and introduce appropriate regulations and practices in the organisation to achieve a balance between work and personal life. 


\section{Problem Statement}

Work life balance has been a concern in today's organisation. With a busy schedule, employees are not able to balance both work and personal live. Due to the fact that certain job are high in demand, employees are working hard to maintain their position by working long hours and maintain a high productivity at work. Many employees are spending more time at work than personal life by bringing their work to their home. Employee that is married and have family experience the most burnout because they have to work long hours and take care of their family. One of the problem that restricts the employees work life balance is working in a negative environment, the lack of awareness toward work life balance and the lack of strategies to promote work life balance (Parakandi \& Behery, 2015). According to Subramaniam, Overton \& Maniam (2015), very few local companies in Malaysia have implemented flexible working arrangement while many multinationals are very proud to highlight this workplace reform. In Malaysia context, a study was done and it showed that $60 \%$ of the Malaysian employees felt that they could not allocate time for their families due to lengthy working hours. According to Hasan \& Teng (2017), studies on work-life, balance in Malaysia is still lacking and most of the studies only highlights female employees, public and private service employees and academician perspective on work-life balance. The work-life balance research can be carried out in many fields, such as private sectors and organizations. Based on the current studies; there is not much empirical study in Malaysia regarding work-life balance and job satisfaction (Hasan \& Teng, 2017). Most of the study that is done in the Malaysian context only focuses on specific group among the working adults. In this research, a wider perspective among Malaysian employee will be focused instead of a specific group.

\section{Research Objectives}

- $\quad$ To investigate the influence of flexible working schedule towards job satisfaction in the service industry.

- $\quad$ To measure the influence of job autonomy towards job satisfaction in the service industry.

- To investigate the influence of emotional intelligence towards job satisfaction in the service industry.

\section{Research Questions}

RQ1: What is the influence of flexible working schedule towards job satisfaction in the service industry?

RQ2: What is the influence of job autonomy towards job satisfaction in the service industry?

RQ3: What is the influence of emotional intelligence towards job satisfaction in the service industry?

\section{Research Hypotheses}

H1: Flexible working schedule has a positive influence towards job satisfaction in the service industry.

$\mathrm{H} 2$ : Job autonomy has a positive influence towards job satisfaction in the service industry.

$\mathrm{H} 3$ : Emotional intelligence has a positive influence towards job satisfaction in the service industry. 
INTERNATIONAL JOURNAL OF ACADEMIC RESEARCH IN BUSINESS AND SOCIAL SCIENCES Vol. 10, No. 7, July, 2020, E-ISSN: 2222-6990 @ 2020 HRMARS

\section{Conceptual Framework}

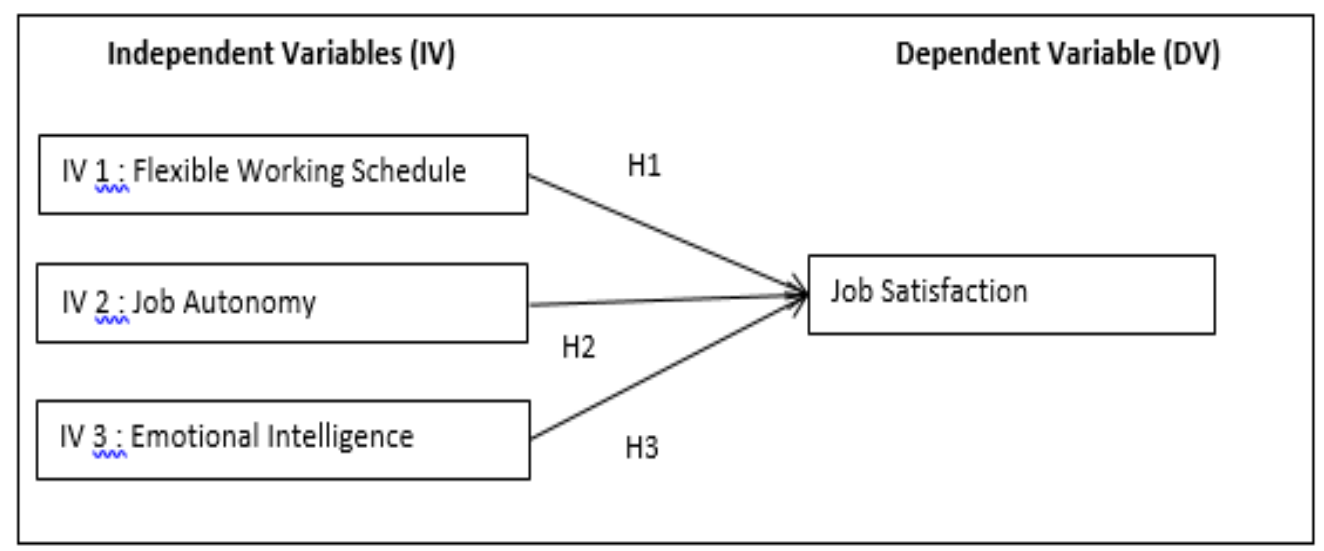

\section{Figure 1: Conceptual Framework}

\section{Literature Review Job Satisfaction}

Many successful organizations rely on their employees high performance in meeting the organizational objectives (Shmailan, 2016). To achieve these organisational goals and maintain the competent level in the organisation, the employees must be able to perform at a high level of satisfaction. Job satisfaction is a predilection of emotions that employees have towards the role that they are performing at the work place (Raziq \& Maulabakhsh, 2015). Maqbali (2015) stated that the idea of job satisfaction is a broad construct that clutches job characteristics and work surroundings. The selection of interpretations of work satisfaction means there are many ways to describe job satisfaction. Locke gave a common description of work satisfaction as a pleasurable or optimistic emotional condition resulting from an evaluation of one's job experience(Menon \& loannou, 2016).Job satisfaction can also be defined as a positive emotion that is resulted by a positive value regarding the job and positive working environment. Most research shows that workers have specific needs, and the degree of job satisfaction is influenced by the extent to which this need is fulfilled (Maqbali, 2015). Job satisfaction is a major problem for many businesses, including highly evolved or third world countries (Gangai \& Agrawal, 2015). Job satisfaction is dependent on organizational variables such as working conditions and organizational structure which in generic point the organizational climate (Valaei \& Rezaei, 2016). A labour-intensive service sector does have a high human touch and values employee satisfaction and organizational contribution more than other sectors (Celik, Dedeoglu \& Inanir, 2015). Job Satisfaction is a critical element of work success, which is connected to an employee's improved productivity and also intrinsic motivation(Hasan \&Teng, 2017).A analysis showed a variety of implications for job satisfaction (Gangai \&Agrawal, 2015). A meta analysis was carried out and it resulted with extraversion and conscientiousness (both positively correlated) as well as neuroticism (negatively correlated) were the most significant traits for professional satisfaction (Mroz \& Kaleta, 2016).A study that was done showed that employees' perception of quality work life can be significantly reinforced by positively addressing their different needs, thereby increasing job satisfaction (Lee, Back \& Chan, 2015).According to Lee, Back \& Chan (2015), satisfied employees have excellent customer service and are able to meet customer loyalty. The research on job satisfaction are without a doubt is seen as a crucial topic to address further since 
INTERNATIONAL JOURNAL OF ACADEMIC RESEARCH IN BUSINESS AND SOCIAL SCIENCES Vol. 10, No. 7, July, 2020, E-ISSN: 2222-6990 @ 2020 HRMARS

it is affecting majority of the employees life (Hasan \& Teng, 2017). All the organisation must pay attention to this topic as it involves the employees and it can be one of the strategic method to achieve the organisational goals. Job satisfaction relates with work life balance because it covers the policies of the organisation in terms of the flexibility in working hours and the benefit it provides to the employees.

\section{Work Life Balance}

The word work-life balance has gained prominence in science, making it easier to understand employee issues. In studies where work-life balance or similar constructs are addressed, researchers appear to use several different methods to operationally define and measure the construct (Borah \& Bagla, 2016). Recent topics include how workers prioritize their positions in the workplace, family, person and society (Gilley et al. 2015). Work-life balance means keeping an individual's work-life style in place (Agarwal \& Lenka, 2015). All work-life balance designed broadly is aimed primarily at helping workers attain a self-determined, well-being state that allows them to achieve goals and objectives in order to effectively manage different tasks in the workplace (Parakandi \& Behery, 2015). Omar et al. (2015) Described work-life balance on how committed and happy a person is with his or her job and private life. There is a growing number of people have been spending more time on work-related activities(Hossain et al. 2018).It is suspected that the work-life balance trend and its development can be investigated, may influence employees 'well-being and job results at work(Md et al. 2014). Goyal \& Babel (2015) explained that work life balance programs are an opportunity to invest in an organization aimed at increasing performance, reducing tranquility, enhancing safety, flexible work and employees' satisfaction. Eighty percent of respondents thought that they had a high degree of tension that could be attributed to both technical and personal factors (Kannan \& Suma, 2015).

\section{Flexible Working Schedule}

Flexible work schedules(FWS), often referred to as flex-time, are the most common form of flexible work arrangements (Hashim, Azman, Ghani \& Sabri, 2016). Flexible working schedules are defined as in which workforce are given larger arrangement freedom in how they carry out the responsibility of their positions (Hafeez \& Akbar, 2015).In an organization, this applies to employees to form a decision on the start and ending of their working hours or days, but within the core time and day given to them. Flexible working has become progressively common in numerous countries in past years, with many employers offering some form of flexible working to their employees and many employees are taking advantage of these chance (Menezes \& Kelliher, 2016). Working environments have a further effect on an employee's satisfaction level (Hafeez \& Akbar, 2015). A recent study found that $79 \%$ of requests from workers with responsibilities who want to switch their working conditions are approved by employers and the most common applications are for flexible work schedules and homework(Prowse \& Prowse, 2015).Organizations with rather modernized employment policies may also be likely to create a flexible working schedules (Zapf \& Weber, 2017). Research has indicated that use of flexible working schedule may improve work-life balance and decrease work pressure(Wheatley n.d.). Employees that are in the organization for many years, with supervising responsibilities and with other co-workers in their working group are more likely to use flexible working schedule and tight workweeks (Zapf \& Weber, 2017). 
INTERNATIONAL JOURNAL OF ACADEMIC RESEARCH IN BUSINESS AND SOCIAL SCIENCES

Vol. 10, No. 7, July, 2020, E-ISSN: 2222-6990 @ 2020 HRMARS

\section{Relationship between Flexible Work Schedule and Job Satisfaction}

A study was done and it stressed that each of the work life balance component on its own is a main predictor of job satisfaction (Goyal \& Babel, 2015). The relationship between flexible work schedule and job satisfaction benefits workers by raising their retention rate, decreasing absenteeism, decreasing conflicts in work-life and tension at work(Wheatley n.d.). Job control over the working hours and improvement have been found to be related with job satisfaction(Menezes \& Kelliher, 2017).Another study that was done revealed that flexible working allow the employee to have a healthier mental health and reduction in stress which eventually leads to higher job satisfaction(Wadhawan, 2019). According to Renmin, Wang \& Weststar, 2014), it was found that employees that experiences work family conflict when they could not spend time with their families have a negative effect on the job satisfaction.

\section{Job Autonomy}

Job Autonomy relates to the capacity and power that workers take in order to fulfill their work obligations (Gohan, Bashir, Abrar \& Asghar, 2015). Another definition that was given by (Gozukara \& Colakoglu, 2016) stated that the degree of independence and freedom pertaining to the job is necessary or permitted to carry out daily work activities. According to (Sultan, Aftab, Amin \& Anjum, 2016), job autonomy is defined as the level of person's power and imprudence given in a working place. According to $\mathrm{Ng} \&$ Ang (2008),Employment autonomy applies to the degree to which workers make their own job-related decisions, such as what duties to perform, how to execute the work and how to manage work exceptions. While according to Kim (2008), the definition of work autonomy may be defined as an individual's level of control over his / her own imminent preparation and duties. There is some evidence that even though workers work hard, they may feel less pleased with their company because they are expected to work openly and make decisions about their own jobs on their own. (Naqvi, Ishtiaq, Kanwal \& Ali, 2013). In the Job Characteristics Model, job autonomy is seen as one of the key role characteristics that can positively affect the psychological condition of the workers and contribute to high work productivity, reduced absenteeism and job satisfaction.(Lin 2011).Autonomy must possibly improve the organizational effectiveness and it motivates employees to perform the job fairly (Olanye \& Eyela, 2017).By fostering the flexibility of their workers, workers believe that completing their tasks is beneficial to their own self-selected goals as they enjoy the job process and appreciate the outcome of the task (Maymon \& Reizer, 2017).

\section{Relationship between Job Autonomy and Job Satisfaction}

A research carried out shows that job autonomy is positively linked to job satisfaction(Preenen, Oeij, Dhondt, Kraan \& Jansen, 2016).It was found that job autonomy was a motivating view on job satisfaction for university workers and also stressed that 'work itself' was the most fulfilling attribute(Amarasena, Ajward \& Haque, 2015). When the satisfaction of needs for autonomy is considered alongside the fulfillment of the needs for relatedness and competency, selfdetermination theory asserts that overall well-being follows (Russell , 2017). The results were largely positive, resulting in job flexibility resulting in worker satisfaction (Chung, 2017). Recently, researchers have argued that work satisfaction should be viewed as positive evaluative decisions individuals make about their work and regarded as an attitude.(Chung, 2017). The concept of personal responsibility for work causes workers to develop beneficial affective and behavioral reactions to their job that improve job satisfaction (Saragih, 2011). 
INTERNATIONAL JOURNAL OF ACADEMIC RESEARCH IN BUSINESS AND SOCIAL SCIENCES Vol. 10, No. 7, July, 2020, E-ISSN: 2222-6990 @ 2020 HRMARS

\section{Emotional Intelligence}

Emotional intelligence is a part of the genetic makeup of an individual but as with any intelligence this too can be developed (Shylaja \& Prasad, 2017). Emotional Intelligence is the ability to warn and monitor even slight changes in one and the other's emotional tones, remain composure in the midst of distress, establish and maintain healthy ties with others (Shelar n.d.). Emotional Intelligence is a collection of attributes and competences that encompasses a wide variety of individual competences and attitudes, typically referred to as interpersonal and intrapersonal competences (Kumar \& Jyothirmai, 2018). The construct of emotional intelligence has been described as the ability to perform effective rational thinking about feelings and the ability to use emotions and emotional awareness to improve cognitive content (Joseph \& Newman, 2015). Emotional intelligence is an important collection of behavioral qualities for performance in questionable environmental pressures(Pradhan, Jena \& Singh, 2017). The concept of emotional intelligence is of utmost importance in the workplace. Aside from qualifications, skills and the abilities an employee possess to get the work done, they should learn the meaning and value of emotional intelligence as they play a crucial role in the organization. Emotional intelligence skills enable employees to control their emotions to cope with stress effectively, to perform well under pressure and to respond to organizational changes(Bhaskar, 2015).Many researchers have agreed that leaders with a high degree of emotional intelligence will develop positive relationships with followers and empower themselves and their employees not just to do their work, but also to do it well (Sinha, 2016). Emotional intelligence is relevant in the service sector, where workers communicate more frequently with customers (Routray, Dash \& Ray, 2017).

\section{Relationship between Emotional Intelligence and Job Satisfaction}

It was found that there was a positive connection between emotional intelligence and work satisfaction, meaning that workers with strong emotional intelligence are once again more pleased with their work(Sinha 2016).In a recent study to examine the impact of emotional intelligence on job satisfaction, it was found that emotional intelligence influences job satisfaction significantly (Tagoe \& Quarshie, 2017). A study of food service employees and their supervisors found a positive relationship between skill-based emotional intelligence and job satisfaction in staff and their supervisors (Kassim, Bambale \& Jakada, 2016). It is commonly held that workers with high emotional intelligence would be happier with their work (Ealias \& George, 2012). It is because workers with a high degree of emotional intelligence can transcend the negative effects by developing solutions to fix the problem and the burden of the immediate environment. As representatives 'emotional intelligence increases, the outcome of their work satisfaction also builds up (Chaturvedi, Mishra \& Yadav, 2017).

\section{Research Methodology Research Design}

A research design is the design of data collection and analysis conditions in a manner, which integrates economic and procedural relevance for the research purpose (Akhtar, 2016). In this research, the research design that was implemented was quantitative method. This quantitative approach was sufficient, because it was able to collect a large amount of data collected and analyzed. The purpose of this descriptive research was to explore the factors (flexible working hours, job autonomy and stay intention) and how it affected job satisfaction among employees in the service 
INTERNATIONAL JOURNAL OF ACADEMIC RESEARCH IN BUSINESS AND SOCIAL SCIENCES

Vol. 10, No. 7, July, 2020, E-ISSN: 2222-6990 @ 2020 HRMARS

industry and how significant the relationship was. By having a research design, it made the process of collecting, measuring and analyzing of data more understanding.

\section{Sampling Technique}

The sampling technique that was used in this study was probability sampling. Probability sampling was based on the assumption that every member of a population was given a known and equal chance of being selected (Glen, 2015). This technique was used due to the large and diverse population size and to aim to creating an accurate sample.

\section{Sampling Population}

A population is usually a large number of individuals or objects that are the principal subject of a scientific investigation (Sekaran \& Bougie, 2016).The target population for this research were employees that were employed in the service industry in Kuala Lumpur. The target population included those who was in the working legal age ranging from 18 to 60 years old. The reason why a large age group was chosen was because the researcher was able to gather more information from various age group and the answers given were more honest and reliable.

\section{Sampling Size}

The sample description stems from the inability of the researchers to test all individuals within a given population (Sekaran \& Bougie, 2016). According to Department of Statistic Malaysia (2017), the amount of population in the service industry had 4,795,721 employees. It was necessary to pick the right sample so as not to waste resources and time. According to Krejcie \& Morgan (1970), the minimum sample for the population of $4,795,721$ employees is 384 .Therefore the minimum respondent for this study was 384 .

\section{Data Collection Method}

The primary data were used to collect data for this analysis. Primary data are data obtained from firsthand sources by a researcher (Glen, 2018). The primary data that was used for the study were questionnaires that was distributed to the respondents in the service industry that is in Kuala Lumpur. An electronic questionnaire was used because it was one of the easiest ways to distribute without having to meet face to face with the respondent and majority of the respondents would prefer answering questions online rather than the conventional way of using pen and paper. It saves cost and time for both researcher and respondent. The questionnaire was created using Google Forms. It was the most convenient way to create question without any hassle of having to pay to use the software. A link was provided in every social media platform to allow the respondents to participate in this study. The secondary data for this study was derived from reliable sources such as journals, article, and books and certified database for the related topic chosen.

\section{Research Instrument}

The key research instrument used in this study was questionnaire, and the questions were both openended and close-ended. Open-ended form are questions that allow someone to give a free-form answer (Farell, 2016).Close-ended form are question that required a yes or no answer. This questionnaire made it easier for the researcher to identify the respondent and made the data collection accurate and relevant. For this research, the questionnaire was divided into two parts, Part 
A: Demographic profile and part B: Factors of Work life balance and its influence on job satisfaction in the service industry. Part A had 7 question that consisted of gender, age, marital status, number of children and which service industry are they in. Part B was measured using a 5-point Likert Scale. A Likert Scale is a type of rating scale used to measure attitudes or opinions (Glen, 2015). A Likert scale assumes that the impact of an attitude on a continuum is linear, strongly disagrees with one another, and assumes that attitudes can be measured (Mcleod, 2019).

\section{Data Analysis}

Data analysis is the method of data evaluation using analytical and empirical reasoning to examine each section of the data collected or provided (Perez, 2019). In this research, an analytical method was used in this research by using a software called Statistical Package for the Social Sciences (SPSS). SPSS is a software that helps researcher to analyze big and large data to produce a simple compiled data set for the researcher to understand the data better. Once all the data was gathered, the software to produce the analyzed data coded it. The data were analyzed using descriptive analysis, normality analysis, analysis of reliability, correlation analysis and analysis of multiple regression.

\section{Descriptive Analysis}

Descriptive analysis gives you an indication of how the data is distributed, helps you spot outliers and typos and allows you to identify associations between variables and ready for further data analysis (Dhand, 2015). The main aim of the descriptive statistics was to provide a brief summary of the samples and the behavior taken in a specific study(Diana n.d.).There were two elements of descriptive analysis, central tendency measurement and variability measurement. The mean, median and mode of the data sets were described primarily in central tendency measurements. In calculating of the variability, it measured the dispersion of the data with standard deviation, range, skewness and variance.

\section{Normality Test}

Normality means that your data followed the normal distribution (Date, 2019). According to Date (2019), several statistical techniques and models assumed that the underlying data was normally distributed. Therefore, a normality test was performed in this study. The reason why this test was performed was to find out whether the sample that were drawn from the population were normally distributed and whether it fits like a bell curve shape. Based on this test, the skewness value and the kurtosis value were derived and analysed. The acceptable range for skewness was between -3 to +3 and kurtosis is between -1 to +10 (Griffin \& Steinbrecher, 2013).

\section{Reliability Test}

A reliability test tells the researcher how reliably a check test performs something and if you apply the same procedure to the same sample under the same conditions you will achieve the same results (Middleton, 2020). While according to Glen (2016), a reliability test is a measure of the stability or consistency of a data set. In this research, the Cronbach's Alpha reliability test was used to find out the reliability of each of the variable dimension. The Cronbach alpha is a metric used to assess the reliability or internal accuracy of a series of scales or test objects (Goforth, 2015). 
INTERNATIONAL JOURNAL OF ACADEMIC RESEARCH IN BUSINESS AND SOCIAL SCIENCES Vol. 10, No. 7, July, 2020, E-ISSN: 2222-6990 @ 2020 HRMARS

\section{Correlation Analysis}

A correlation test is a two-variate analysis of the relationship strength between two variables and the direction of the relationship (Magiya, 2019). This analysis targeted to evaluate the correlation between both the predictor variables and the dependent variables. The changes in the magnitude of one variable was associated in correlated data with a change in the magnitude of another variable, either in the same direction or in the opposite direction (Patrick, Christa \& Lothar, 2018).The coefficient of correlation ( $r$ ) is always between +1 and -1 (Rumsey n.d.). The higher the correlation value, the stronger the relationship is.

\section{Regression Analysis}

Regression analysis is a reliable method for determining which variables influence an important subject (Foley 2018).Multiple linear regression analysis was used for the research. The variability of the independent variables in the dependent variable was taken linearly into consideration for multiple regression analysis (Uyanik \& Guler, 2013). R-Square $\left(R^{\wedge} 2\right)$ explained the variance which was generated by the SPSS to determine the percentage of the variance in job satisfaction by the factors of flexible working hours, job autonomy and intention to leave. The $\beta$-value generated as the representation of the regression coefficient. In this research, the level of significance was set at 0.05 . If the value is below 0.05 , the hypothesis will not be rejected and if they value is above 0.05 , they hypothesis rejects.

\section{Results, Findings and Discussion Descriptive Analysis}

The total respondents collected were 390.The respondents that contributed more into this research were women with a percentage of $61.5 \%$ or 240 respondents while male respondent contributed $38.5 \%$ or 150 respondent. The researcher collected $21.8 \%$ of the data from respondents aged $18-25$ years old,29.7\% of the data from respondents aged $26-33$ years old,30.3\% of the data from respondents aged $34-41$ years old, $10.8 \%$ of the data from respondents aged $42-49$ years old and $7.4 \%$ of the data came from respondents aged 50 and above. Majority of the data came from middle aged employees aged 34-41 years old while the lowest contributor of the data were senior workers aged 50 and above. Majority of the respondents that contributed to this data analysis was married employees with a percentage of $52.3 \%$, which was half of the data of marital status. For respondents that are single; they contributed $37.4 \%$, while divorced respondents contributed $7.4 \%$ to this study. $2.1 \%$ of the data came from respondents that are separated from their significant other and $0.8 \%$ came from others, to be more specific, being in a relationship the researcher found out that the majority of the respondents that answered the questionnaire does not have children (37.4\%). While $31.0 \%$ of the respondents have 1 child. $20.0 \%$ of the respondents have 2 children and $9.2 \%$ of the respondents have 3 children. The lowest was $2.3 \%$, where the respondent responded to having four and above. Majority of the respondents were from the tourism industry (29\%) and healthcare industry (29\%). While $16.2 \%$ were from the hospitality industry, $21.3 \%$ of the respondents were from telecommunication industry and $4.6 \%$ of the respondents responded with others. The others included having their own business that provides services and working as a company secretary that provides services for other companies.18.7\% of the respondents has been working in the service industry less than 5 years, while 30.3\% of the respondents have been in the industry for 6-10 years. $26.7 \%$ of the respondents responded that they have been in the industry for $11-15$ years and 
INTERNATIONAL JOURNAL OF ACADEMIC RESEARCH IN BUSINESS AND SOCIAL SCIENCES Vol. 10, No. 7, July, 2020, E-ISSN: 2222-6990 @ 2020 HRMARS

$13.1 \%$ have been working in the service industry for $16-20$ years and the remaining $11.3 \%$ responded that they have been working for more than 21 years in the service industry. The income of the respondents, the highest contributor to this data was respondents that earns RM3001-RM4000 which was $42.8 \%$. Respondents that earned below RM1000 were $1.8 \%$ which is also the lowest contributor to this data analysis, RM1001-RM2000 were $10.3 \%, \mathrm{RM} 2001-\mathrm{RM} 3000$ were $28.2 \%$ and respondents that earned RM4001 and above were $16.9 \%$. The majority of the respondents came from employees who worked 40 hours in a week, which is equivalent to $67.9 \%$. The respondents who worked less than 40 hours per week is $4.9 \%$ and the respondents who worked more than 40 hours per week is $26.2 \%$. Others in this part of the answer was to see if employees in the service industry worked other than the hours stated and $1.0 \%$ answered that they worked according to their own time, which the researcher assumed that these respondents run their own business or they are the employer of a place.

\section{Normality Test}

In this research, the normality test was used to find out the distribution of the sample size. This test was crucial because it helps the researcher to understand if the sample that was collected falls within the range of skewness $(-3$ to +3$)$ and the kurtosis $(-10$ to +10$)$.If the sample collected are not normally distributed, and then other techniques will be used to test the data. The lowest value for the skewness value was 0.258 while the highest skewness value was 0.452 . For the kurtosis value, the lowest value was -1.085 while the highest value for the kurtosis was -0.714 . Both these items were within the range of the kurtosis, therefore they were normally distributed. Overall, the data for skewness value and kurtosis value were all within their range and most of the item was normally distributed.

\section{Reliability Test}

In this research, Cronbach's Alpha was used to test the consistency and the reliability of this research. If the Cronbach's Alpha is above 0.7, the reliability of the questions is acceptable and is reliable for the research. From Table 1, we can evaluate that all of the independent variable presented in this research was above $\alpha<0$.9. Flexible working Schedule had a value of 0.939.Job Autonomy had a value of 0.950 and Emotional intelligence had a value of 0.936 . We can conclude that all the items in this research were reliable and consistent.

Table 1: Result of Reliability Test

\begin{tabular}{lcc}
\hline Items & Cronbach's Alpha & Number of Items \\
\hline Overall Variables & 0.951 & 18 \\
Job Satisfaction & 0.791 & 6 \\
FlexibleWorking Schedule & 0.939 & 6 \\
Job Autonomy & 0.950 & 6 \\
Emotional Intelligence & 0.936 & 6 \\
\hline
\end{tabular}


INTERNATIONAL JOURNAL OF ACADEMIC RESEARCH IN BUSINESS AND SOCIAL SCIENCES Vol. 10, No. 7, July, 2020, E-ISSN: 2222-6990 @ 2020 HRMARS

\section{Correlation Analysis}

There was a strong relationship between flexible working schedule and job satisfaction. Both variable had a very strong correlation $(r=0.892, p<0.01)$. The correlation analysis that was done supported that the independent variable, flexible working schedule had strong positive relationship with the dependent variable, job satisfaction. The researcher concluded that $\mathrm{H} 1$ was supported and accepted. There was a strong relationship between job autonomy and job satisfaction. Both variable had an excellent correlation $(r=0.932, p<0.01)$. The correlation analysis that was analyzed supported that the independent variable, job autonomy had a strong positive relationship with the dependent variable, job satisfaction. The researcher concluded that the $\mathrm{H} 2$ was supported and accepted.

There was a medium strong relationship between emotional intelligence and job satisfaction. Both variable had a moderately strong correlation $(r=0.683, p<0.01)$. The correlation analysis that was done for this variable supported that emotional intelligence has a medium positive relationship with the job satisfaction. Therefore, the researcher concluded that the H3 was supported and accepted.

Table 2: Result of Pearson Correlation

Job



**. Correlation is significant at the 0.01 level (2-tailed). 
INTERNATIONAL JOURNAL OF ACADEMIC RESEARCH IN BUSINESS AND SOCIAL SCIENCES

Vol. 10, No. 7, July, 2020, E-ISSN: 2222-6990 @ 2020 HRMARS

\section{Regression Analysis}

Table 3 Model Summary

\begin{tabular}{|l|l|l|l|l|}
\hline Model & R & R Square & Adjusted R Square & Std. Error of the Estimate \\
\hline 1 & $.608^{\mathrm{a}}$ & .360 & .355 & .683 \\
\hline
\end{tabular}

a. Predictors: (Constant), Emotional Intelligence, Flexible Working Schedule, Job Autonomy

b. Dependent Variable: Job Satisfaction

In Table 3, the computed $\mathrm{R}$ Square was 0.360 . The results informed us that all the three variable, flexible working schedule, job autonomy and emotional intelligence was considered for $36 \%$ of the differences in job satisfaction towards work life balance in the service industry. While $64 \%$ of the variance in factors influencing job satisfaction towards work life balance in the service industry remained as unsearched factors. While the R-Square is lesser than $50 \%$, therefore the researcher conclude that there are still factors that can affect the job satisfaction in the service industry which are yet to be discovered and researched by other researcher.

Table 4: ANOVA

\begin{tabular}{|c|c|c|c|c|c|}
\hline Model & & $\begin{array}{l}\text { Sum } \\
\text { Squares }\end{array}$ & of $\mathrm{df}$ & $\begin{array}{l}\text { Mean } \\
\text { Square }\end{array}$ & Sig. \\
\hline & \multirow{3}{*}{$\begin{array}{l}\text { Regression } \\
\text { Residual } \\
\text { Total }\end{array}$} & 86055.152 & 3 & \multirow{3}{*}{$\begin{array}{l}28685.051 \\
.308\end{array}$} & \multirow[t]{3}{*}{$93173.151 .000^{b}$} \\
\hline & & 118.837 & 386 & & \\
\hline 1 & & 86173.990 & 389 & & \\
\hline
\end{tabular}

a. Dependent Variable: Job Satisfaction

b. Predictors: (Constant), Emotional Intelligence, Flexible Working Schedule, Job Autonomy In table 4, the significance value was shown. Since the value of Alpha, $\alpha$ was 0.05 and the P-value was 0.01. Therefore the researcher conclude that the value of $P$ is lesser than the value of alpha, $\alpha(P(0.01)$ $<\alpha(0.05)$.The model is deemed fit for the analysis. When the $P<0.05$, the results in the table was statistically significant.

Table 5: Coefficients

\begin{tabular}{llllll}
\hline Model & \multicolumn{2}{l}{$\begin{array}{l}\text { Unstandardized } \\
\text { Coefficients }\end{array}$} & \multicolumn{2}{l}{$\begin{array}{l}\text { Standardizedt } \\
\text { Coefficients }\end{array}$} & \multirow{2}{*}{ Sig. } \\
\cline { 2 - 4 } & B & Std. Error & Beta & & \\
1 & .078 & .122 & & .641 & .522 \\
FlexibleWorking Schedule & 1.015 & .009 & .439 & 117.776 .000 \\
Job Autonomy & .982 & .010 & .390 & 98.712 & .000 \\
Emotional Intelligence & .998 & .006 & .359 & 167.305 .000 \\
\hline
\end{tabular}

a. Dependent Variable: Job Satisfaction 
INTERNATIONAL JOURNAL OF ACADEMIC RESEARCH IN BUSINESS AND SOCIAL SCIENCES

Vol. 10, No. 7, July, 2020, E-ISSN: 2222-6990 @ 2020 HRMARS

In table 5, the standardized coefficient beta represented the coefficient of regression that analyses a unit change in the predictor variables when the predictor changes independently. The higher the $\beta$ value, the higher the influence of independent variable to the dependent variable. By examining all of the $\beta$-value for all three independent variables, it was shown that flexible working schedule $(\beta=0.439)$ has the highest influence on job satisfaction. The lowest $\beta$-value was emotional intelligence $(\beta=0.359)$. While the $\beta$-value for job autonomy was $\beta=0.390$. The results of the multiple regression analysis was summarised. When the value of $\alpha$ is 0.05 , the value of flexible working hours, job autonomy and emotional intelligence were less than 0.05 , therefore the researcher can conclude that all the variable had a positive influence on the job satisfaction in the service industry and therefore, $(\mathrm{H} 1, \mathrm{H} 2$ and $\mathrm{H} 3)$ were not rejected. It showed that flexible working schedule $(\beta=0.439$, $n=390, p<0.05$ ) had a significantly positive influence on job satisfaction in the service industry. This means that the research hypothesis $(\mathrm{H} 1)$ was not rejected. It revealed that job autonomy $(\beta=0.390$, $n=390, p<0.05$ ) had a positive influence on job satisfaction in the service industry. Therefore, the researcher concluded that Hypothesis $(\mathrm{H} 2)$ was not rejected. It showed that emotional intelligence $(\beta=0.359, n=390, p<0.05)$ had a significantly positive influence on job satisfaction in the service industry. Therefore, hypothesis (H3) was not rejected.

\section{Conclusion and Recommendation}

Work life balance has been one of the problem that is being significantly researched in the organization because it is very essential to have a balanced work-life. Being able to work and have a balanced life is crucial to have a healthy mental and physical health. Factors of work life balance is studied to understand better about how it influences employees' job satisfaction in the work place. This research focused on employee who were from the service industry that were working around Kuala Lumpur. Quantitative research was used for this researched. The population of employees from the service sectors was $4,795,721$ employees and the sample size that was chosen from the population was 384.A set of questionnaire was sent to the respondents and before it was sent to the respondent, the reliability and validity of the questionnaire was done so it would be seen as a reliable questionnaire to the respondent. The procedure of the study involved sending out the questionnaire through social media and hard copy is available for employees who prefer hard copy to soft copy. The questionnaire took 10-15 minutes to be filled and it will be conducted for 3 weeks. Various methods were used to interpret the data and a deeper analysis of the data will be done. An analysis of the data was done and the implication and suggestions were given at the end of the research paper.

The findings of this research will be useful to the service industry companies around Malaysia, as they will understand more about the factors of work life balance if they seek to improve employees' job satisfaction in the company. Once organization understand the employees, they will benefit from this because instead of just learning employees' behavior in the workplace, they create a relationship that will last between organization and employees in the service industry. Information that is collected from this research will deemed useful as it may be a way to create strategies to improve the employees' well-being. Flexible working schedule has a high influence on job satisfaction. Employees who works with a flexible working schedule reported to have a high productivity in their work, which resulted in a higher job satisfaction. When an employee is satisfied with their job, they are willing to work in the organization. Employees are balancing their life with work and personal life. Therefore, they are able to produce more output during working hours knowing that they can also spend 
adequate time with their friends and family. Job autonomy was also seen to have a high influence on job satisfaction. When a decision power is given to the employee, they are able to work on their own terms and are able to make decision without the aid of their employees. It makes employees to have a sense of belonging in the company and to be appreciated for their effort and decision making process. This ultimately led to a higher job satisfaction and the ease of employees working in an environment where their output is relevant to the situation. Emotional intelligence has a positive relationship with job satisfaction. When an employee has a high emotional intelligence, they are able to think rationally and solve problems using facts and figure. This is crucial in an organization because they are responsible for ensuring that the relationship between employee and employers are always positive. When they are happy with the situation and when employees are able to understand each situation with emotional intelligence, the satisfaction of their job increases. Therefore, company always conduct trainings for employees on how to manage emotions at workplace and how to separate personal emotions from work. Having a low emotional intelligence may affect the decisionmaking process and it may lower the job satisfaction of oneself.

Majority of the respondents will be based in Klang Valley, which has one of the highest workforces in Malaysia. Although Klang Valley is the main area for most of the businesses, the results may vary for employees who work in other area in the state. Other factors can be considered other than the three independent variables that was stated in this research to deepen the research of this topic. Research could be done to a broader view among employees especially in the whole of Malaysia. Another limitation in this research is the use of language. The main language that is used in this research is English. It would create a minor problem to those who does not speak English as their first language. It would create a barrier for the participants to understand and answer the questions that is provided. It may affect the results and findings of this research. Therefore, in the future, researchers can produce bilingual questionnaire to ease the process of collecting data from respondents that has language barrier. The research objective focused on the influence of job satisfaction in the service industry. Future researcher may expand their research to other industry to understand their views on the topic given. The organizations are rapidly changing every time and the way we work is also changing, therefore with the help of this research, it may be useful for employers to reduce the gap between the employees and employers and their relationship with the organization.

\section{References}

Adom, D., Hussein, E. K., Joe, A. A. (2018). Theoretical and Conceptual Framework: Mandatory Ingredients of a Quality Research, International Journal of Scientific Research, vol. 7, no. 1,pp. 438-441,viewed 22 January 2020,<https://www.researchgate.net/publication/322204158_THEORETICAL_AND_CONCEP TUAL_FRAMEWORK_MANDATORY_INGREDIENTS_OF_A_QUALITY_RESEARCH>.

Agarwal, S., Lenka, U. (2015). Study on work-life balance of women entrepreneurs - review and research agenda, Industrial and Commercial Training, vol. 47,no. 7,pp. 356-362, viewed 10 March 2020,<https://www.emerald.com/insight/content/doi/10.1108/ICT-01-20150006/full/html>.

Albattat, A. R., Som, A. P. M., Helalat, A. S. (2014). Higher Dissatisfaction Higher Turnover in the Hospitality Industry, International Journal of Academic Research in Business and Social Sciences, vol. 4,no. 2,pp. 45-52,viewed 13 January 
INTERNATIONAL JOURNAL OF ACADEMIC RESEARCH IN BUSINESS AND SOCIAL SCIENCES

Vol. 10, No. 7, July, 2020, E-ISSN: 2222-6990 @ 2020 HRMARS

2020,<http://citeseerx.ist.psu.edu/viewdoc/download?doi=10.1.1.685.4424\&rep=rep1\&typ $\mathrm{e}=\mathrm{pdf}>$.

Bhaskar, P. (2015). Emotional Intelligence and Job Performance in Service Industry, International Journal of Research in Computer Application \& Management, vol. 5, no. 2,pp. 60-65, viewed 9 February 2020,<https://www.researchgate.net/publication/283319240_EMOTIONAL_INTELLIGENCE_ AND_JOB_PERFORMANCE_IN_SERVICE_INDUSTRY>.

Biegger, A., Geest, S. D., Schubert, M., Ausserhofer, D. (2016). The 'magnetic forces' of Swiss acute care hospitals: A secondary data analysis on nurses' job satisfaction and their intention to leave their current job, Nursing Plus Open, vol. 2,pp. 15-20,viewed 20 January 2020,<https://www.sciencedirect.com/science/article/pii/S2352900816000030>.

Byden, M. (2016). Flexible Work Arrangements: Stress-Buffering or Stress exacerbation? Bachelor thesis, Goteborgs Universitet.

Celik, S., Dedeoglu, B. B., Inanir, A. (2015). Relationship Between Ethical Leadership, Organizational Commitment and Job Satisfaction at Hotel Organizations,Ege Academic Review,vol. 15, no. 1,pp. 53-63,viewed 13 January 2020,<https://dergipark.org.tr/en/download/articlefile/560390>.

Chaturvedi, V., Mishra, P., Yadav, D. S. (2017). Investigating the Relationship between Emotional Intelligence and Resulting Job Satisfaction among Faculty Fraternity in Selected Colleges in NCR, Amity Journal of Management Research, vol. 2, Iss. 1, pp. 20-36, viewed 15 February 2020,<https://amity.edu/UserFiles/admaa/f3d5ePaper\%203.pdf>

Chung, E. (2017). The relationship between Job Autonomy, Job Satisfaction and the mediating role of Job Crafting, BSc Human Resource Studies, Tilburg University.

Department of Statistics Malaysia. (2017). Economic Census 2016- Services Sector,Department of Statistics Malaysia,Kuala Lumpur.

Forris, S. E. (2015). The Quest for Work and Family Balance Using Flexible Work Arrangements, Doctor of Philosophy Applied Management and Decision Sciences, Walden University, viewed 8 February

2020,<https://pdfs.semanticscholar.org/14d1/e70e84808cb0e4b385bd2c5dc278ca57206d. pdf $>$.

Goyal, K. A., Babel, A. A. (2015). ssues and Challenges of Work Life Balance in

Banking Industry of India,Pacific Business Review International,vol. 8,Iss. 5,pp. 113-118,viewed 10 March 2020,<http://oaji.net/articles/2016/3050-1456206153.pdf>.

Hashim, A., Azman, N. S., Ghani, M. A., Sabri, M. F. M. (2016). The Relationship Between Work-Life Balance and Employee Retention, proceeding of the 3rd International Conference on Management \& Muamalah 2016 (3rd ICoMM), viewed 16 January 2020,<http://conference.kuis.edu.my/icomm/3rd/eproceedings/IC-031.pdf>.

Hossain, M. I., Limon, N., Amin, M. T., Asheq, A. S. (2018). Work Life Balance Trends: A Study on Malaysian GenerationY Bankers, Journal of Business and Management, vol. 20,Iss. 9,pp. 19, viewed 10 March 2020,<https://www.researchgate.net/publication/328094884_Work_Life_Balance_Trends_ A_Study_on_Malaysian_GenerationY_Bankers $>$. 
INTERNATIONAL JOURNAL OF ACADEMIC RESEARCH IN BUSINESS AND SOCIAL SCIENCES Vol. 10, No. 7, July, 2020, E-ISSN: 2222-6990 @ 2020 HRMARS

Jamaluddin, A., Gunaseelan, A., Jusoh, Z. M. (2015). Relationship Between Emotional Intelligence and Job Satisfaction Among Texas Instruments Employees, Australian Journal of Business and Economic Studies,vol. 1,no. 2,pp. 31-39, viewed 27 February 2020,<https://www.aabss.org.au/system/files/published/001004-published-ajbes.pdf>.

Joseph, D., Boyle, E. O., Newman, D. A. (2015). Why Does Self-Reported Emotional Intelligence Predict Job Performance? A Meta-Analytic Investigation of Mixed El, Journal of Applied Psychology, vol. 100,no. 2,pp. 298-342,viewed 10 February.

2020,<https://www.researchgate.net/profile/Daniel_Newman9/publication/287205621_Jos eph_Jin_Newman_O'Boyle_2015/links/5673181e08ae04d9b099c08c.pdf>.

Kassim, S. I., Bambale, A. J., Jakada, B. A. (2016). Emotional Intelligence and Job Satisfaction among Lecturers of Universities in Kano State: Empirical Evidence, Journal of Education and Practice, vol. 7,no. 10,pp. 53-59,viewed 13 February 2020,<https://files.eric.ed.gov/fulltext/EJ1099468.pdf>.

Kannan, P., Suma, U. (2015). Managing Stress among Co-Operative Bank Employees in Palakkad district, International Journal of Scientific Engineering and Applied Science. (IJSEAS),vol.1,Iss. 7,pp. 132-137, viewed 10 March 2020,<http://ijseas.com/volume1/v1i7/ijseas20150714.pdf>.

Kshirsagars, S. R. (2018). Work-Life Balance of Women Employees in Service Sector, International Journals of Advanced Research in Computer Science and Software Engineering, vol. 8,no. 1,pp. 1-6,viewed 13 January 2020,<https://www.researchgate.net/publication/323593340_WorkLife_Balance_of_Women_Employees_in_Service_sector_A_Pilot_Study $>$.

Kumar, R. S., Jyothirmai, K. M. (2018). Emotional Intelligence and Work Life Balance of Employees In Retail Sector, International Journal of Research and Analytical Reviews, vol. 5,Iss. 4,pp. 380387, viewed 9 February 2020,<http://www.ijrar.org/papers/IJRAR1944435.pdf>.

Lee, J. S., Back, K. J., Chan, E. S. W. (2015). Quality of work life and job satisfaction among frontline hotel employees, International Journal of Contemporary Hospitality Management, vol. 27, Iss. 5,pp. 768-789,viewed 15 January 2020,<http://si.secda.info/chihching_course1/wpcontent/uploads/2017/09/10.-Lee-2015-Quality-of-work-life-and-job-satisfaction-amongfrontline-hotel-employees.pdf>.

Milliman, J., Gatling, A., Kim, J. S. (2018). The effect of workplace spirituality on hospitality employee engagement, intention to stay, and service delivery, Journal of Hospitality and Tourism Management, vol. 35,pp. 56-65, viewed 19 January 2020,<https://etarjome.com/storage/panel/fileuploads/2019-08-19/1566213151_E12567-e-tarjome.pdf>.

Patrick, S., Christa, B., Lothar, S. (2018). Correlation Coefficients: Appropriate Use and Interpretation, Anesthesia \& Analgesia, vol. 126,Iss. 5,pp. 1763-1768,viewed 27 January 2020,<https://journals.Iww.com/anesthesia-

analgesia/Fulltext/2018/05000/Correlation_Coefficients_Appropriate_Use_and.50.aspx>.

Pradhan, R., Jena, L., Singh, S. (2017). Examining the role of emotional intelligence between organizational learning and adaptive performance in Indian manufacturing industries, Journal of Workplace Learning, vol. 29,no. 3,pp. 235-247,viewed 19 February 2020,<https://www.emerald.com/insight/content/doi/10.1108/JWL-05-20160046/full/html>

Raziq, A., Maulabakhsh, R. (2015). Impact of Working Environment on Job Satisfaction ,Procedia Economics and Finance, vol. 23,pp. 717-725, viewed 15 January 
INTERNATIONAL JOURNAL OF ACADEMIC RESEARCH IN BUSINESS AND SOCIAL SCIENCES

Vol. 10, No. 7, July, 2020, E-ISSN: 2222-6990 @ 2020 HRMARS

2020,<https://www.sciencedirect.com/science/article/pii/S2212567115005249?via\%3Dihub $>$

Russell, M. (2017). The Relationships among Autonomy, Job Satisfaction and Motivation, Honors Theses, University of North Georgia.

Sekaran, U., Bougie, R. (2016). Research-Methods-For-Business-A-Skill-Building-Approach-7th edition, Library of Congress Cataloging-in-Publication Data, viewed 28 February 2020,Academia. 